\title{
Historein
}

Vol $10(2010)$

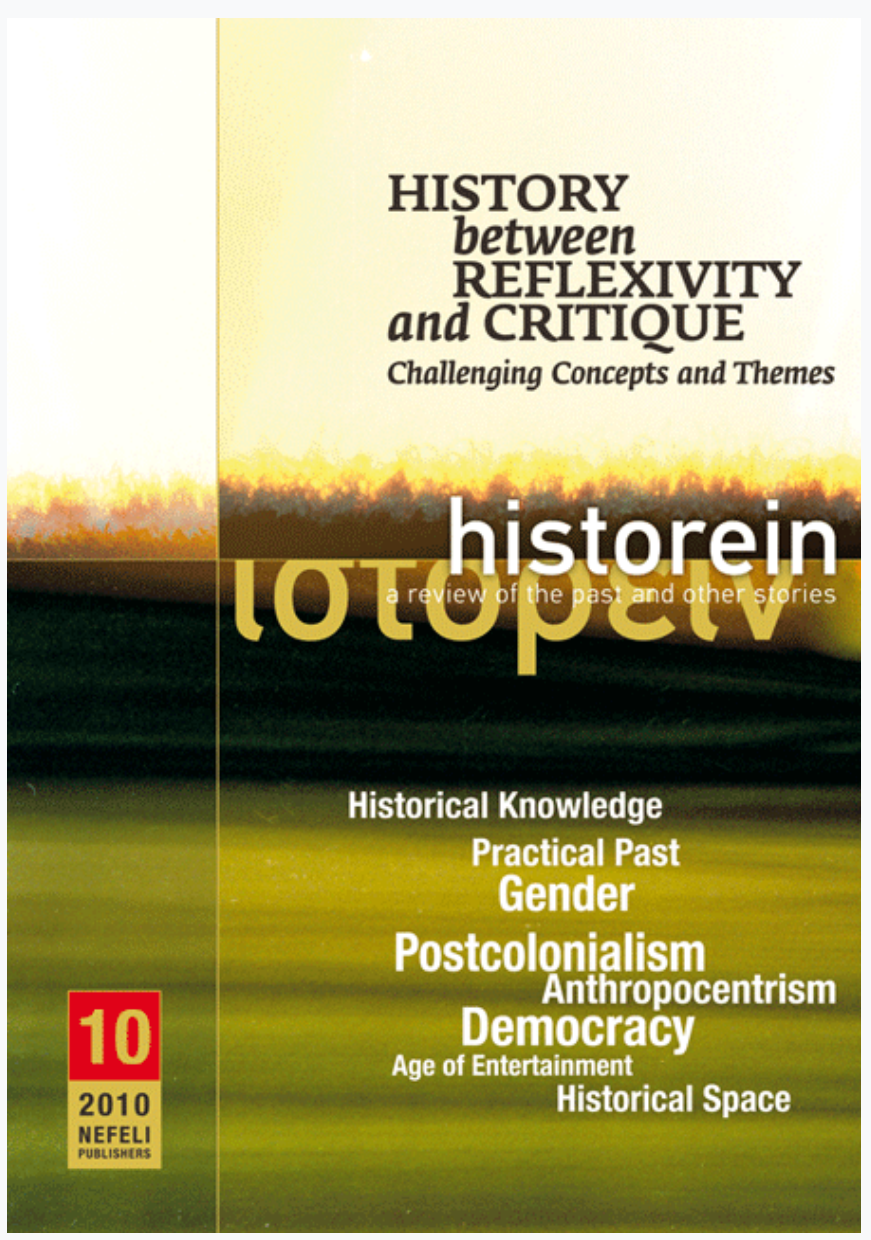

\section{What is Historical Critique About?}

Antonis Liakos

doi: $10.12681 /$ historein.13

Copyright @ 2012, Antonis Liakos

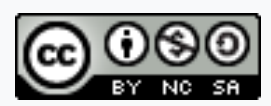

This work is licensed under a Creative Commons Attribution-NonCommercialShareAlike 4.0.

To cite this article:

Liakos, A. (2011). What is Historical Critique About?. Historein, 10, 144-152. https://doi.org/10.12681/historein.13 


\section{What is Historical Critique About?}

Antonis Liakos University of Athens
What is the meaning of historical critique? What is historical critique like? Is it possible, as Hayden White asks, for historical thinking to be reformulated as a kind of critique ? $^{1}$ The starting point of this article is to consider the doings and practices of historians from outside, by distancing ourselves from our familiarity with history, historians and historical activities. Often, we imagine history as an open window to the past, but in this article we will look at history as the windows of a building, i.e., as a cultural feature of the societies in which we live in. Through this reversal of the gaze from outwards to inwards, history matters not as a cognitive activity but as a cultural practice. But history is not only Jacob's nightly wrestling with the angel of the past. It is part of our public knowledge and is linked to governance, not because it accumulates useful knowledge or constructs useful narrations for the purposes of governing but because educates us on how to know, deal and think about the past. Two concepts are central to this paper: critique and governmentality. Governmentality, a term introduced by Foucault, refers to the complex set of relationships with the past that are used to transform and subjugate the mentalities and behaviours of modern societies. From this point of view, history matters as a means to teach shared cultural and moral values; as a means to create bonds and identities through the construction of a common past; as an exercise in public behaviour through the discipline of knowledge, ideas and opinions about the past; as a way to tame the unfulfilledness and as a guardian against the memories-ghosts of the past from taking revenge and disturb- 
ing the order of the present. History as public knowledge has rules, standards and criteria not incompatible with the civic and cultural standards of the societies which feed it.

Starting from the current uses of history as a "cultural resource" and reflecting on the experiences of history and criticism of recent decades, this article intends to discuss a shift in the agenda of writing a history of historiography, one quite different from the more familiar histories of historical writing or of histories of the institutional arrangements of the past. It advocates a history based on the questioning of the role of history. In this history, governance - which, in its broad sense, is the governmental utilisation of culture for specific ends - would appear central, contributing to the definition of historical culture. ${ }^{2}$ Such an attempt aspires to reflect on how the doings of historians acquire unintended meanings in the context of the power relations in which we are living, and the means of communication we use to articulate our voice.

\section{History as a cultural resource}

During 2008, the year of the outbreak of the economic crisis, an article appeared in a major Greek daily arguing that a possible way out of the misfortune befalling the Greek economy would be a reorientation towards a new concept of development, which could be summarised in three words: History, sun and sea. ${ }^{3}$ For the author of the article, the comparative advantage of Greece, besides the sun and the sea, lay in its long and glorious past. He meant the classical past, already a tourist attraction, but argued that Greece could also become a place that could host in situ students and professors in their studies of archaeology, history and philosophy, as well as training and publication agencies, all of which would create employment and revenue. The idea of history as a cultural resource is commonly raised outside university lecture halls and is related to the public historical sphere which comprises a wide range of institutions, from museums to heritage sites but also television historical dramas and documentaries, historical novels and commemorative days and monuments. It also embraces ways of thinking about and reacting to history and memory issues, such as past collective experiences, questions regarding identities and aspirations towards justice or, even, revenge. The public historical sphere regards all the ways through which the present social and political realities are related to the past, and inside this sphere, the question of accuracy and truthfulness is peripheral or, rather, performative. History should appear verisimilar, impersonal, to be based on documents and traces, the authentic voice of the past. ${ }^{4}$

Academic history, although pledged to the idea of accuracy, is not outside this sphere, and it is increasingly subjected to old and new types of demands. Political actors (parties, governmental and international organisations) used to sponsor history institutes in order to polish their past and to provide historical depth to their choices; big business whitens its past through history; and large, private cultural institutions have entered the realm of "respectable" history production. History is a big field in which cultural capital, symbolic power and distinction amass. The 


\section{What is Historical Critique About?}

mass media has become the main vehicle for the diffusion of historical ideas. Big political turns are closely associated with schematised historical accounts of the past that impose a severe institutionalisation of memory. A whole range of regulations and official commemorations regarding what and how we should remember (or not) has been passed by national legislatures, the European Parliament and international organisations. The quest for the institutionalisation of particular memories has led to memory and history wars within and across borders, to wars of recognition, but also wars of revenge..$^{5}$

The massive changes in historical culture have accompanied the mass demand for history. Before nationalism, history was a product of a few for the few. It was a concern of the learned elites. During the long era of print capitalism and nationalism, history was popularised but still remained a product of the few for the many. Now, in passing from the world of print to the virtual world, history has entered the realm where everyone can claim the right to write about the past, memory and history and has the means to diffuse his products. The use of the internet and the virtualisation of historical resources have enormously facilitated the thirst for memory and the need for recognition. Suffering, forgiveness and memory as a plea for justice or as revenge have become part of a cultural constellation in which history is conceived. The past has acquired a new cyberface, which includes all possible kinds of mirrors. The entry of history into the realm of "popular cyberculture" has transformed historical culture. Professional historians are no longer able to rule over the new vast empire of history. They inhabit this landscape of historical culture and play a range of roles, the prime one being a provider of institutionalised authority to various versions of the past.

The question is how historians conceive and enact their role in history-making today. May they continue to claim the guardianship of memory? Can they continue to perceive their role as the guarantors of historical truth? Is it they who decide the historical agenda? Does it make sense to distinguish and choose between a practical or critical role in shaping historical culture? Most of the debates on history regard the role of historians, the meanings attributed to history, the weight and the significance of historical knowledge, the relationship between history and justice and professional ethics. ${ }^{6}$

\section{Generational experience}

My generation was brought up to regard the concept of critique as central to its intellectual and civic project. Critique was particularly important in Greek historical scholarship from two aspects: First, for cleaning up the intellectual legacy of the dictatorships and civil war. Second, for dealing with the concept of Hellenism and the ideological lineage of national continuity, which burdened the way academics and the public conceived history. Central to this project was the analysis of the "ideological use of history" by Philippos Iliou, a leading historian and influential intellectual of the Left. The "ideological use of history", presupposing a nonideological use, has since the 1970s become a key-phrase in the texts and the attitudes of a whole generation of historians.' Sweeping myths, distortions and ideological uses of history became the main drive, and the underlying plot, of Greek historiography. Following the restoration of democracy in Greece, the rewriting of history and the change in historical sense became one of the central intellectual projects in the country's democra- 
tisation, which often saw historians becoming public intellectuals addressing a national audience. ${ }^{8}$

While declaring that the reconstitution of history would involve elevating it to the status of a science, this historical tradition was not constrained to a pure academic history irrelevant to any practical use of the past. Quite the opposite: Iliou used to paraphrase the evangelical phrase "the truth will liberate you", arguing that the truth would have more revolutionary potentiality than historical, even leftist, myths. This tradition was linked to history as critique and was performed as one of the stronger cultural critiques in a range of issues such as the use of history in the Macedonian question, the re-elaboration of the past by the Church, the burning of the secret police files, and the history of the civil war. But at the heart of this critique was a sound contradiction: the weeding out of the past was done in the name of uninterested history - but for practical reasons. Indeed, this concept of critique was conceived as a pledge of scientific history against any political, ideological or literary use of history. But it remained restricted to an image of objectivism, and defensive against the cultural turn, poststructuralism and the linguistic turn, feminism and postcolonial studies. It remained bound to a binary distinction between the ideological and nonideological use of history and alien, even unreceptive, to the critique of the cognitive presuppositions, to the language, the gender and the social status of history. What has happened is that, thirty years later, critique without reflexivity had become fossilised, and without a target.

\section{The genealogy of critique}

The debate on critique started with Immanuel Kant's idea that critique is the suspension of judgment. The meaning of this phrase is that we suspend the action of judging in order to think about the framework, values and mental categories with which we evaluate, condemn or appreciate things, ideas or persons. For Kant, this suspension of judgment involved finding out the general rules and criteria that ought to govern our judgment. For historians, the way to Kant passes frequently through Foucault. Indeed he politicised this suspension of judgment, saying that it is an action of disobedience and resistance to the spiritual authorities because it brings under scrutiny their postulates to govern, the values and mental acceptances with which we are governed. The aim of critique is not to explore ecumenical laws but the opposite: to show how ecumenical laws have been formed and legitimised as general truths and rules. For Foucault, critique is genealogy but not the genealogy of ideas external to us. Critique is the enquiry of how are we constituted as subjects of our own knowledge. The aim of Foucault was to develop a "critical ontology of ourselves".?

But how has critique related to history since Kant? For Marx, the writing of history was a form of critique because it allows us to understand how the ideas that dominate as natural and universal truths are the result of concrete circumstances in the past. From this point of view, critique becomes synonymous with the concept of historicity. This idea has echoed in the postmodern critique. Indeed, Judith Butler emphasises the historicity of the mental categories that have formed the self, and Joan Scott argues for the role of poststructuralism in turning historiography into a critical practice in the late twentieth century. ${ }^{10}$ Researching the historicity of the ideas and practices with which we are governed - critical history, by creating distance and disaffection 


\section{What is Historical Critique About?}

- might make it possible to see that the mental categories with which we conceive the world in which we live are precarious and contingent. This thought might lead us to conceive the world as an open field of possibilities, and not as the field of "there is no alternative" which sanctifies the implementation of prevailing political choices. But critique is not external to what we are doing and to how we are thinking. Critique meets reflexivity as the critique of the social and cultural presuppositions of our knowledge.

\section{Way out and way in}

Since the Enlightenment, critique, as immanent to the study of society and culture, has differentiated between "critique as withdrawal from" and "critique as engagement with". "Critique as withdrawal from" takes the form of a total negation which, considering the state of things as a system of domination that cannot be transformed, aims at the intellectual exodus from it. Foucault explained the meaning of this critique when referring to Kant's perception of the Enlightenment as an Ausgang, an "exit", or a "way out", of the older system of thought. ${ }^{11}$ The second form, "critique as engagement with", requires an idea of a critique based on the admission that society cannot be considered without division and power, beyond any need for law, states and politics. It recognises that some contradictions are irreducible and cannot be eliminated, but only mediated, through politics. From this point of view, critique is a form of engagement with the object of critique. ${ }^{12}$ These two aspects of critique also determine the concept of critique in history. Should historians choose between a way out of and a way into historical culture? Taking the way out means searching for a radical alternative to the conventions and the presuppositions of being historical in an attempt to test the limits of historicality. It means to think how the world became historical and how we started to think the world in terms of history, to realise that history does not stand alone but is one of the antagonistic ways of seeing the world. The way out involves seeing history not from inside as a discipline but from outside as a cultural practice. This transposition of history from the realm of epistemology to the realm of culture opens new questions. The most important is how history is linked to governmentality.

\section{Governmentality}

Governmentality is a concept introduced by Foucault and refers to the art and rationalities of governing, where the conduct of conduct is the key activity. ${ }^{13}$ It is an attempt to reformulate the governor-governed relationship, beyond administrative or juridical practices and institutions, and beyond the state. It refers to diffused practices, not to one-sided impositions. It points out the ways subjects become governable, not through coercion but through the forming of their aspirations and needs, through the implementation of distinctive ways of seeing and perceiving, of thinking and questioning. From this point of view, history educates people in a way of thinking which eliminates the past from the future and reality from the desire to change it. It offers a set of values, of which rational governance is the most important, and proposes general guidelines for social cohesion and particular narratives of national cohesion. Historical critique does not contrast the cognitive with the normative dimension of history but relates both to other discipli- 
nary practices that create subjects amenable to be governed. Seen this way, history becomes a form of the disposition of power. From this point of view, the dilemma for historians is either to choose to be a performer of historical discipline, that is, to act as an expert on the past, or to follow the way out in searching for the limits of historical knowledge and for demonstrating how historicality is connected to governmentality. Historical critique as a suspension of judgment is not to judge what we should remember and should forget, but to problematise remembering and forgetting in terms of governmentality but also of resistance. Critique and resistance are two concepts that are often related. But resistance is not associated with a permanent resisting agency but to specific practices that may be resistant at one level and performative at another. For example, the concept of cultural diversity, which represents one of the stronger challenges to the homogenising culture of the nation-state, is partially the result of resistance but also of new techniques of control which are more efficient in decentralising than centralising activities and subjectivities. The concept of tolerance, also, is the result of the resistance to intolerance and discrimination, but also means the privatisation of difference; it is a substitute for equality and has been considered a technique of governmentality. ${ }^{14}$

The discussion on governmentality, though consolidated in its present form during the 1990s, as a discussion about the way the dense relations between people and people, people and things, and people and events are understood and acted on through a wide range of strategies in order to secure the well-being of each and of all, is practically a discussion that started in the late 1970s and is related to Foucault's later work. The notion as such provides an umbrella for his older ideas on power, knowledge and disciplinarisation as applied in modern societies, only that this time the lens are reversed. ${ }^{15}$ Foucault gives a threefold definition of governmentality: First, as "the ensemble formed by institutions, procedures, analyses and reflections, calculations, and tactics that allow the exercise of this very specific, albeit very complex, power that has the population as its target, political economy as its major form of knowledge, and apparatuses of security as its essential technical instrument". Second, "the tendency, the line of force, that for a long time, and throughout the West, has constantly led towards the preeminence over all other types of power - sovereignty, discipline, and so on - of the type of power that we can call "government" and which has led to the development of a series of specific governmental apparatuses (appareils) on the one hand, [and, on the other,] to the development of a series of knowledges (savoirs)". Third, "the process or rather, the result of the process by which the state of justice of the Middle Ages became the administrative state in the fifteenth and sixteenth centuries and was gradually governmentalized". ${ }^{16}$ In other parts of his lectures, he sums up his definition of governmentality as the art of government, as dealing with "the phenomena of politics, that is to say, interests, which precisely constitute politics and its stakes; it deals with interests, or that respect in which a given individual, thing, wealth, and so on, interests other individuals or the collective body of individuals". ${ }^{17}$ Though issues of imposition of power, knowledge and disciplinarisation were not new to the Foucaultian discourse (and had already had a political impact in the antipsychiatry reform of the 1970s), now the interest was focused from the bottom up, to the way citizens affirm to this imposition by embodying it, especially in the context of liberal regimes.

The political context within which the discussion is inscribed, namely liberalism, wellfarism and neoliberalism, provided the necessary fuel for it to flourish in the environment of the Thatcher- 


\section{What is Historical Critique About?}

ite UK and the Reaganite USA, which was already experiencing the decline of its social security system during the 1980s. The political situation encouraged the discussion of governmentality, in other words of the role that the state has to hold in order to keep its citizens under control, without interfering too much in the societal realm (since the Cold War was not yet over, not even in the ideological realm). So, when the notion of governmentality left the faculty of philosophy in France, it was taken on mainly by political scientists. Nikolas Rose, Peter Miller, Mariana Valverde, Pat O'Malley, Tony Bennett, Alan Hunt and Ted O'Leary are only some of the scholars that elaborated on governmentality in multiple ways, giving governmentality studies their current form.

In a very sketchy approach, governmentality nowadays means studies on technologising the self, biopolitics, cultural management and the way cultural institutions are used as agents for the imposition of the dominant ideas on security and risk; the forming of networks that can help the work of governance; disciplinarisation not through imposition of power but through expectation of fulfilment; the responsibility of the individual for his or her future and capability. In other words, though disciplinarisation has not changed as such, what has changed in the new context is the way it is imposed and the way the individual is held responsible not for obeying but for incorporating the rules of comportment to his or her mentality. When this has happened, then $\mathrm{s} /$ he has the freedom of moving within the accepted limits. ${ }^{18}$

\section{Way in}

Historical culture, as well as the historical discipline, is not a homogeneous field of power but a place where cultural conflicts take place over the form of history. What should historians do and how should they intervene? What is their role?

We should be conscious that a unique response is no longer possible. Since the 1970s, the tribe of historians has changed. It is no longer a tribe of white, middle-class men but has been transformed into a conglomeration of men and women, coming from the old metropolises and former colonies, of different social status, colour and faith, associated with many disciplines, methods and conceptions of the past. How may we envisage historical criticism under these terms?

If the common ground of historians is to establish a conscious relationship with the past, this role has some minimum social and moral requirements. We have seen irresponsible uses of history in ethnic conflicts, we have seen the rise of memory from the ruins of totalitarian states, and we often find ourselves in the midst of history wars. On the other hand, we have seen historians working in the difficult conditions of restrained freedom, dealing with murderous pasts, as is the past of most of the dictatorships of the planet. They are historians who risk their life, and who feel that doing history represents a formidable challenge for their personal integrity and civic responsibility. ${ }^{19}$ As a consequence, critique as "engagement with" is not an exclusive alternative to the critique as a "way out". Both are aspects of historical critique. What are not compatible with historical critique are the innocence and the theoretic naivety with which historians accept their instrumentalisation while defending their scientific purity. What is not compatible 
with historical critique is the illusion of being critical in doing history with no other reference or consequence outside our small case study. ${ }^{20}$ Sometimes historians forget what Clifford Geertz said: "anthropologists don't study villages, they study in villages."21

\section{Impact and relevancy}

The problem is not to draw a borderline between reflexive and unreflexive, critical and uncritical historiography. It is rather to ask how historical critique might have a broader impact, how relevant it is to the big choices we are faced with, how history could be self-reflexive and avoid being self-referential. Historians were highly efficient as nation makers but less influential at making critiques of the nation. Does this mean that the disjunction of history writing from nation building has deprived history of its audience? Even social history had a role in the forming of radical and new social subjectivities during the 1960s and 70s. But, since then, and under the shadow of the linguistic and cultural turns, the distance between the historical community and society has become larger and larger. This is surprising given the explosion in the production of historical films and television programmes and the new wave of historical museums, thematic parks and heritage sites. Does this mean that history is concerned less with the past as the object of historical scholarship, than the useful past, the past as nostalgia, the venerated or discriminated past, the past to which we are still bound? Or it is the consequence of an ongoing separation of the spheres of historical theory and history writing? It is true that critique as the suspension of judgment and historical self-reflexivity is a metalanguage not easy comprehensible by an audience educated in unique truths and solid responses. But historical education in its critical dimension is an education in scepticism, which deals with all the steps of history making and with the uses of history, from the archives to the master narratives. If the problem is to save historical critique and self-reflexivity and to render it more efficient, then we should translate this metalanguage of history into the everyday language of our practical work as historians. But the problem of accessibility to the big audiences has to be understood through the study of historiography as a form of historical culture.

\section{NOTES}

1 Hayden White, "Afterword: Manifesto Time" in Keith Jenkins, Sue Morgan, Alun Munslow, Manifestos for History, London: Routledge, 2007, 220-32 (224).

2 Tony Bennett, "Intellectuals, Culture, Policy: The Technical, the Practical, and the Critical", in Cultural Analysis 5 (2006) (socrates.berkeley.edu/ caforum/volume5/vol5_article4.html, accessed 26 September 2010).

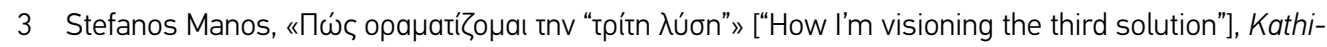
merini, 14 September 2008.

4 Patrick Right, On Living in an Old Country: The National Past in Contemporary Britain, London: Verso, 


\section{What is Historical Critique About?}

1985, 188; Tony Bennett, The Birth of the Museum: History, Theory, Politics, London: Routledge, 1995, 132.

5 Antonis Liakos, "History Wars: Notes from the Field", Yearbook of the International Society for the Didactics of History 2008/09: 57-74.

6 Martha Minow, Between Vengeance and Forgiveness, Boston: Beacon, 1992; Olivier Dumoulin, Le rôle social de l'historien: de la chaire au prétoire, Paris: Albin Michel, 2003; Jeffrey Blustein, The Moral Demands of Memory, New York: Cambridge UP, 2008.

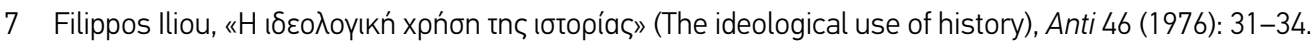

8 Antonis Liakos, “Modern Greek Historiography (1974-2000): The Era of Tradition from Dictatorship to Democracy" in Ulf Brunnbauer (ed.), (Re)Writing History: Historiography in Southeast Europe after Socialism, Münster: LIT Verlag, 2004, 351-78.

9 Michel Foucault, "What is Critique?" in his The Politics of Truths, ed. S. Lotringer, Los Angeles: Semiotext(e), 2007, 41-82.

10 Judith Butler, "What is Critique? An Essay on Foucault's Virtue", in Transversal (August 2006) (transform.eipcp.net/transversal/0806/butler/en, accessed 26 September 2010); Joan Scott, "History-writing as Critique", in Manifestos for History, 19-38.

11 Foucault, "What is Enlightenment?" in The Politics of Truths, 97-120.

12 Bennett, "Intellectuals, Culture, Policy”. Chantal Mouffe, “Critique as Counter-Hegemonic Intervention”, in Transversal (April 2008) (eipcp.net/transversal/0806/muffe/en, accessed 26 September 2010).

13 Graham Burchell, Colin Gordon, Peter Miller (eds), The Foucault Effect: Studies in Governmentality, Chicago UP, 1991.

14 Tony Bennett, "Culture and Govenmentality", in Jack Z. Bratich, Jeremy Packer, Cameron McCarthy, Foucault, Cultural Studies and Governmentality, New York: State University of NY Press, 2003, 61; Wendy Brown, Regulating Aversion: Tolerance in the Age of Identity and Empire, Princeton, Princeton UP, 2006, 78-106.

15 As expressed mainly in the works The History of Madness (1961, English trans. 2006) and Discipline and Punish: The Birth of the Prison (1975, English trans. 1977).

16 Michel Foucault, Security, Territory, Population: Lectures at the College de France, 1977-78, ed. Michel Senellart, New York: Palgrave Macmillan, 2007, 144.

17 Foucault, The Birth of Biopolitics: Lectures at the College de France, 1978-79, ed. Michel Senellart, New York: Palgrave Macmillan, 2008, 45.

18 Nikolas Rose, Pat O'Malley, Mariana Valverde, "Governmentality", Annual Review of Law and Social Science 2 (2006): 83-104.

19 Antoon de Baets, Responsible History, Oxford \& New York: Berghahn, 2008.

20 For a critical reassessment of the course from social to cultural history, see Geoff Eley, A Crooked Line: From Cultural History to the History of Society, Ann Arbor: University of Michigan Press, 2005; Patrick Joyce, "The Gift of the Past: Towards a Critical History", Manifestos, 88-97.

21 Clifford Geertz, The Interpretation of Cultures, New York: Basic, 1973, 22-25 (my emphasis). 